\title{
LINEAR PROGRAMING MODEL FOR PELLETIZED BAGASSE RATION
}

\author{
T. H. Ghanem*, M. A. Shetawy**, M. M. Geasa*** and \\ M. B. Gomaa $* * * *$
}

\begin{abstract}
The aim of the present study is to predict new large animal feed ration using bagasse by densification process with the aid of soy bean, bran, corn, molasses, bagasse and slate using linear programing model to get the optimal feed mixture from the view point of minimization of the total cost and maximization of nutritional value of the animal feed. Bagasse of moisture content $10 \pm 1 \% \mathrm{w} . \mathrm{b}$ was crushed to $3-7 \mathrm{~mm}$ and prepared at three different controlled moisture contents 30, 35 and $40 \%$, three different mixture temperature 35, 50 and $65{ }^{\circ} \mathrm{C}$ using controlled temperature water bath, then compressed through 6, 8 and $10 \mathrm{~mm}$ die diameters at three different pressure levels of 7.5, 10 and 12.5 MPa. The cost of the new alternative ration is less than the traditional one by $26 \%$.
\end{abstract}

\section{INTRODUCTION}

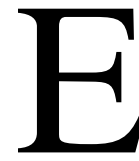
gypt cultivates about (325) thousand faddans of sugar cane every year, which produce 4.87 million tons of bagasse. Sugarcane bagasse is a secondary by-product of sugar cane extraction factories. It is used in the manufacture of pressed fibrous woods, paper pulp and as fuel. Bagasse represents $25-30 \%$ of the sugar cane plant Ministry of Agriculture, Egypt (2014). Sugarcane bagasse is the fibrous residue of Sugarcane after the extraction of juice. Bagasse, as agro-based fibers, have the composition, properties and structure that make them suitable for uses such as composite, textiles, pulp and paper manufacture and animal feed, among others Narendra and Yang, (2005). In order to reduce industry's operational cost as well as to meet the requirement of raw material for animal feed production, industry wastes must be processed and handled in an efficient manner.

\footnotetext{
*Prof. and Deputy Dean of Fac. Of Agric. Eng. Cairo ** Assoc. Prof. of Agric. Eng. Fac. Of Agric. Eng. Cairo *** Lecturers of Agric. Eng. Fac. Of Agric. Eng. Assiut ****Administrator of Agric. Eng. Fac. Of Agric. Eng. Assiut
} 
Due to its high moisture content, irregular shape and size, and low bulk density, waste is very difficult to handle, transport, store, and utilize in its original form Sokhansanj et al., (2005). Densification of waste into durable compacts is an effective solution to handling problems and it can reduce material waste. Densification can increase the bulk density of waste from an initial bulk density of $40-200 \mathrm{~kg} / \mathrm{m} 3$ to a final compact density of 600-1200 kg/m3 Adapa et al., (2007). The density of pellet is calculated from the mass and volume (measuring the length and diameter) of compacts. In general, the density of pellets from agricultural straw significantly increases with an increase in applied pressure Adapa et al., (2010); Kaliyan and Morey, (2009) and Mani et al., (2004). The density of pellet is calculated from the mass and volume (measuring the length and diameter) of compacts. In general, the density of pellets from agricultural straw significantly increases with an increase in applied pressure Kaliyan and Morey (2009). Also indicated that the durability of corn Stover or switch grass briquettes was significantly affected by pressure, moisture content and preheating temperature, while particle size did not have any significant effect. Serrano et al. (2011) found that the highest mechanical durability reached for barley straw pellets was $95.5 \%$ at moisture content of 19-23\% (w.b.), while no pellets were formed below the $19 \%$ moisture content. According to Ministry of Agriculture, Egypt (2014) total bagasse yearly produced in Egypt is accounted 400000 ton. Most this huge quantity are incinerated in open areas causing a fatal effect to human beings. Present study aimed to change previously mention huge amounts of bagasse to be an alternative feed ration to prevent environment of this incredible source of pollution and converting it to be a solution to animal feeds and meat crises.

\section{MATERIALS AND METHODS}

\subsection{MATERIALS}

Experimental study was carried out in the workshop of the Faculty of Agricultural Engineering, Al-Azhar University Assiut, branch during 2015.

\subsubsection{Raw material}

SOY BEAN, CORN, BAGASSE, MOLASSES AND BRAN. 


\subsubsection{Raw material preparation}

\subsubsection{Collecting of samples}

Sugarcane bagasse residues were collected after juicing process of about $42.7 \%$ moisture content w.b, of a bulk density about $170 \mathrm{~kg} / \mathrm{m}^{3}$. Samples were first sun dried and then cut into small pieces $2-3 \mathrm{~cm}$ followed by cutting of $3.0-7.0 \mathrm{~mm}$. Wheat bran, soy meal, salts and metals were collected from open market in Assiut - Egypt and stored in clean polythene bags. Cane molasses were also stored in plastic jars till they are used in the present work.

\subsection{Linear programming approach to the ration formulation problem} Linear programming model Microsoft Office Excel (2010) was developed to select optimal diet composition based on minimization of the total cost and maximization of nutritional value of the new selected nontraditional large animal feed ration. Microsoft Office Excel Solver add-Ins (2010) was used to solve the linear programming model to get the optimal feed mixture from the view point of minimization of the total cost and maximization of nutritional value of the animal feed.

In the program model grind grains: corn, wheat bran and soy bean of previously known nutritional components were used. Sugarcane crushed bagasse of $10 \pm 1 \%$ moisture content and molasses ratios of $15 \%$ were also fed to the model for maximizing the nutritional value of the new and nontraditional alternating large animal feed ration and minimization of their total cost. Diets composition was optimized by the model.

To determine the feed pellet ingredient combinations the model of a linear programming was built as follows:

The objective function:

$$
Z=c_{1} x_{1}+c_{2} x_{2}+c_{3} x_{3}+c_{4} x_{4}+c_{5} x_{5}
$$

Where: $Z=$ Minimum cost.

The model is subjected to the following constraints of the basic nutritional requirements for large animal feed (Ruminants) recommended by the National Research Council NRC (1994): 

$\mathrm{A} \mathrm{a}_{1} x_{1}+a_{2} x_{2}+\mathrm{a}_{3} x_{3}+a_{4} a x_{4}+a_{5} x_{5} \geq 14 \%$
$\mathrm{B} b_{1} x_{1}+b_{2} x_{2}+b_{3} x_{3}+b_{4} x_{4}+b_{5} x_{5} \geq 65 \%$
C $c_{1} x_{1}+c_{2} x_{2}+c_{3} x_{3}+c_{4} x_{4}+c_{5} x_{5} \leq 15 \%$
D $x_{3}=5$ or 10 or $15 \%$
E $x_{4} \geq 20 \%$
$\mathrm{F} x_{1}+x_{2}+x_{3}+x_{4}+x_{5}=90$ unit
$\mathrm{G} x_{1}, x_{2}, x_{3}, x_{4}$ and $x_{5} \geq 0$

Where: $\mathrm{X}_{1}, \mathrm{X}_{2}, \mathrm{X}_{3}, \mathrm{X}_{4}$, and $\mathrm{X}_{5}$ soy bean, corn, molasses, bagasse, and bran respectively, and;
$\mathrm{A}$ : Crude protein ratio $(\mathrm{CP})$;
B: Total digestible nutrients (TDN) system as a measure of energy,
C: Crude fiber $(\mathrm{CF})$,
D: Molasses ratio,
E: Sugarcane bagasse,
F: Quantity of components per mass unit and
G: No negativity constraint.

\subsection{Pellets forming piston-cylinder assembly}

The mechanical forming process involves the application of a compressive force on the material enclosed in a cylinder of an inside $8 \mathrm{~cm}$ diameter, $20 \mathrm{~cm}$ length, 9 die holes and replaceable dies diameters of 6,8 and $10 \mathrm{~mm}$ used for compressing pellets Fig. (3.1) showed carver 12 ton hydraulic unit Source of manufacture: USA, Model: 3912 and Max load: 12 ton.

\subsection{Measuring instruments}

\subsubsection{Digital Caliper}

Digital vernier caliper was used for measuring pellets dimensions Model: TESA 1p65, Useful range: $0-150 \mathrm{~mm}$ and Full accuracy: $0.01 \mathrm{~mm}$ 


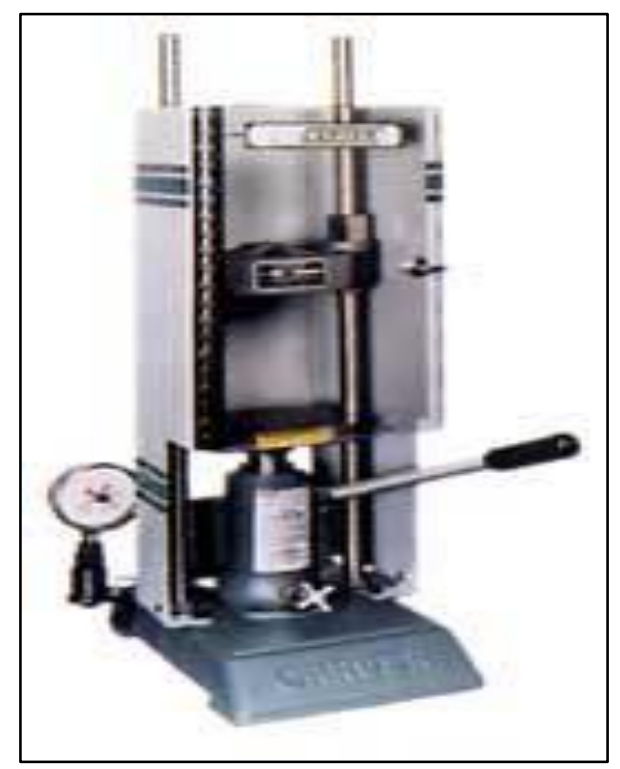

Fig. (3.1): Carver 12 ton hydraulic unit

\subsubsection{Electric digital balance}

Weights of samples were measured by an electrical balance source of manufacture: Korea, Model: THP-600, Useful range: $600 \mathrm{~g}$ and Accuracy of $0.01 \mathrm{~g}$.

\subsubsection{Electrical heater}

Electrical heater used for heating pellet mixtures before compression processing.

\subsubsection{Electric oven}

Electric oven used for oven method moisture contents evaluation of the following specification drying oven Model: $655 \mathrm{~F}$ and Useful range: 250 ${ }^{\circ} \mathrm{C}$.

\subsubsection{Infrared thermometer}

Infrared thermometer used for mesuring formating mixtures temperaturs of the following specification Model: 8865 , Useful range: $50-580{ }^{\circ} \mathrm{C}$ and having accuracy of $0.1^{\circ} \mathrm{C}$.

\subsection{Measurements}

\subsubsection{Moisture content}

The moisture content was determined according to the method of ASAE (2003) S358.2. About $25 \mathrm{~g}$ of the mixture samples were placed in an oven 
at $103{ }^{\circ} \mathrm{C}$ for $24 \mathrm{~h}$. The moisture content was then calculated according to the following equation:

$$
\mathrm{MC}=\frac{\mathrm{w}_{\mathrm{m}-} \mathrm{w}_{\mathrm{d}}}{\mathrm{w}_{\mathrm{m}}} \times 100
$$

Where: M. C: Moisture content of basis \%.

$$
\mathrm{W}_{\mathrm{m}} \text { : Moist weight } \mathrm{g} \text { and } \mathrm{W}_{\mathrm{d}} \text { : Dry weight } \mathrm{g} .
$$

Produced pellets were dried at room temperature until their moisture content reached about $10 \% \pm 1 \%$.

\subsubsection{Pellet quality Evaluation}

\subsubsection{Pellet durability}

Durability measurement of a single pellet for three replicates was carried out using drop test. Single pellet was dropped from a $1.85 \mathrm{~m}$ height on a metal plate. The mass retained is expressed as the percentage of the initial weight Al-Widyan and Al-Jalil (2001). Each drop test was replicated three times. The durability was calculated as:

$$
\text { Durability } \%=\frac{\text { Mass of pellets after dropping }}{\text { Mass of pellets before dropping }} \times 100
$$

\subsubsection{True density of Pellet}

The density of each individual pellet was obtained by measuring the length, diameter and mass using electronic caliper and electronic balance. To have uniform length, the edges of the pellets were smoothed according to Shankar et al. (2007) and Peter, (2014). Pellet density is an average value of three replicates. The true density was calculated as

$$
\begin{aligned}
& V_{b}=\frac{\pi}{4} D^{2} L \\
& \rho_{d}=\frac{m_{b}}{V_{b}} .
\end{aligned}
$$

Where: $\rho_{d}$ : True density of pellets, $\left(\mathrm{kg} / \mathrm{m}^{3}\right)$

$m_{b}$ : Mass of the pellets $(\mathrm{kg})$; and

$V_{b}:$ Volume of the pellets $\left(\mathrm{m}^{3}\right)$

\subsubsection{Bulk density}

The bulk density of pellets is calculated by measuring the bulk weight of the pellets filling a pre-defined volume according to ASABE (2002). 
Measurements were repeated three times for all samples. The bulk density was calculated as:

$$
\rho_{\mathrm{b}=\frac{\mathrm{m}_{\mathrm{c}}}{\mathrm{v}_{\mathrm{c}}}}
$$

Where: $\rho_{b}$ : Bulk density $\left(\mathrm{kg} / \mathrm{m}^{3}\right)$

$\mathrm{m}_{\mathrm{c}}$ : Mass of sample in the cylinder $(\mathrm{kg})$ and

$\mathrm{v}_{\mathrm{c}}$ : Volume of cylinder $\left(\mathrm{m}^{3}\right)$.

\subsubsection{Cost analysis}

The operating cost of producing the new untraditional alternation large animal feed (L. E./h ) was calculated according to Awady (1978) and the production cost for producing one ton of the alternation animal feed was also calculated as follows:

$$
\text { Production cost }=\frac{\text { Operation cost }(\text { L.E. } / \mathrm{h})}{\text { Machine productivity (ton } / \mathrm{h})} \text { L.E./ton...... }
$$

\section{RESULTS AND DISCUSSION}

\subsection{Prediction of ration formulation using linear programing}

In present study linear programing Microsoft Excel (2010) was used for minimizing predicted alternative nontraditional large animal feed rations costs and maximizing their nutritional values using the NRC (1994) recommendations. The new nontraditional alternative ration was predicted and cleared in Table (4.1)

Table (4.1): Composition of the predicted ration

\begin{tabular}{|l||c|}
\hline \hline Composition & Percentage \% \\
\hline \hline Bagasse & 25 \\
\hline \hline Soy- bean meal & 21 \\
\hline \hline Wheat bran & 29 \\
\hline \hline Molasses & 15 \\
\hline \hline Calcium carbonate & 5 \\
\hline \hline Vitamins & 3.5 \\
\hline \hline salt & 1.5 \\
\hline \hline Total & $100 \mathrm{~kg}$ \\
\hline
\end{tabular}

\section{According by NRC 1994.}

\subsection{Pellet quality evaluation}

In present work predetermined different rations composition using simplex model was used for producing compressed pellet. 
The effect of three different pressure levels 7.5, 10 and 12.5 MPa on true density, bulk density and durability were studied with changing other different operating parameters namely: three different controlled moisture contents 30, 35 and $40 \%$, three different mixtures temperatures 35,50 and $65{ }^{\circ} \mathrm{C}$ and die diameters of 6,8 and $10 \mathrm{~mm}$ were studied for evaluating the optimal pellet quality.

\subsubsection{Effect of mixture temperature on durability of pellets.}

Table (4.2) and Figs.(4.1), (4.2), (4.3) showed that there is a direct proportion between durability and mixture temperature for studied ranges of $35-65{ }^{\circ} \mathrm{C}$ at constant applied pressure. These results agreed with Abedin, (2012).

\subsubsection{Effect of applied pressure on pellets durability.}

Table (4.2) and Figs.(4.1), (4.2), (4.3) showed also that there is a direct proportion between applied pressure and pellets durability for all studied ranges of moisture contents $30-40 \%$ w.b and mixture temperature ranges of $35-65^{\circ} \mathrm{C}$ and molasses ratio of $15 \%$.

For all studied ranges and condition linear form of durability as affected by applied pressure and mixture temperature were satisfied.

Table (4.2) and Figs.(4.1), (4.2), (4.3) showed also that maximum value of durability is $97.9 \%$ at $8 \mathrm{~mm}$ die diameter, $30 \%$ moisture content, applied pressure $12.5 \mathrm{MPa}$ and $50{ }^{\circ} \mathrm{C}$.

Figs.(4.1) through (4.3) cleared that durability increases from 1.33 to 9.61 when applied pressure increased by $1 \mathrm{MPa}$ at constant moisture content w.b, mixture temperature range from $35-65^{\circ} \mathrm{C}$ from all tested die diameters in the pressure work.

Large slope does not used as an indication for optimal durability of pellets. Optimal durability may by occurred due to interactions between operational parameter, i.e die diameter, mixture temperature, moisture content and increment of temperature due to applied pressure that decompose the fibrous components of lignocellulose of bagasse, which agreed with Samson and Duxbury (2000). 
Table (4.2): Values of durability as affected by applied pressure and different mixing temperatures at constant moisture content w.b

\begin{tabular}{|c|c|c|c|c|c|}
\hline \multirow{3}{*}{$\begin{array}{c}\text { Die size } \\
\text { mm }\end{array}$} & \multirow{3}{*}{$\begin{array}{c}\text { Moisture } \\
\% \text { (.w.b) }\end{array}$} & \multirow{3}{*}{ T. ${ }^{\circ} \mathbf{C}$} & \multirow{2}{*}{\multicolumn{3}{|c|}{$\begin{array}{c}\text { Durability (\%) } \\
\text { Pressure Mpa }\end{array}$}} \\
\hline & & & & & \\
\hline & & & 7.5 & 10 & 12.5 \\
\hline \multirow{9}{*}{6} & \multirow{3}{*}{30} & 35 & 75.1 & 85.1 & 88.1 \\
\hline & & 50 & 78.9 & 87.9 & 90.9 \\
\hline & & 65 & 83.4 & 91.1 & 97.4 \\
\hline & \multirow{3}{*}{35} & 35 & 84.1 & 87.8 & 92.4 \\
\hline & & 50 & 88.9 & 89.9 & 93.9 \\
\hline & & 65 & 91.1 & 91.4 & 95.1 \\
\hline & \multirow{3}{*}{40} & 35 & 72.1 & 81.8 & 87.1 \\
\hline & & 50 & 89.9 & 91.9 & 94.9 \\
\hline & & 65 & 91.7 & 93.9 & 94.4 \\
\hline \multirow{9}{*}{8} & \multirow{3}{*}{30} & 35 & 88.1 & 92.6 & 95.1 \\
\hline & & 50 & 90.9 & 93.9 & 97.9 \\
\hline & & 65 & 91.0 & 94.4 & 97.4 \\
\hline & \multirow{3}{*}{35} & 35 & 85.1 & 91.1 & 93.1 \\
\hline & & 50 & 91.4 & 92.9 & 94.8 \\
\hline & & 65 & 92.4 & 93.4 & 95.4 \\
\hline & \multirow{3}{*}{40} & 35 & 84.1 & 89.1 & 91.1 \\
\hline & & 50 & 90.9 & 93.3 & 93.9 \\
\hline & & 65 & 93.4 & 95.4 & 95.4 \\
\hline \multirow{9}{*}{10} & \multirow{3}{*}{30} & 35 & 79.13 & 91.13 & 93.13 \\
\hline & & 50 & 86.9 & 92.9 & 94.9 \\
\hline & & 65 & 91.4 & 93.8 & 96.2 \\
\hline & \multirow{3}{*}{35} & 35 & 89.13 & 90.13 & 93.13 \\
\hline & & 50 & 89.5 & 91.35 & 92.9 \\
\hline & & 65 & 89.37 & 90.96 & 92.07 \\
\hline & \multirow{3}{*}{40} & 35 & 69.13 & 78.63 & 88.35 \\
\hline & & 50 & 84.51 & 86.35 & 90.90 \\
\hline & & 65 & 84.36 & 87.37 & 91.37 \\
\hline
\end{tabular}




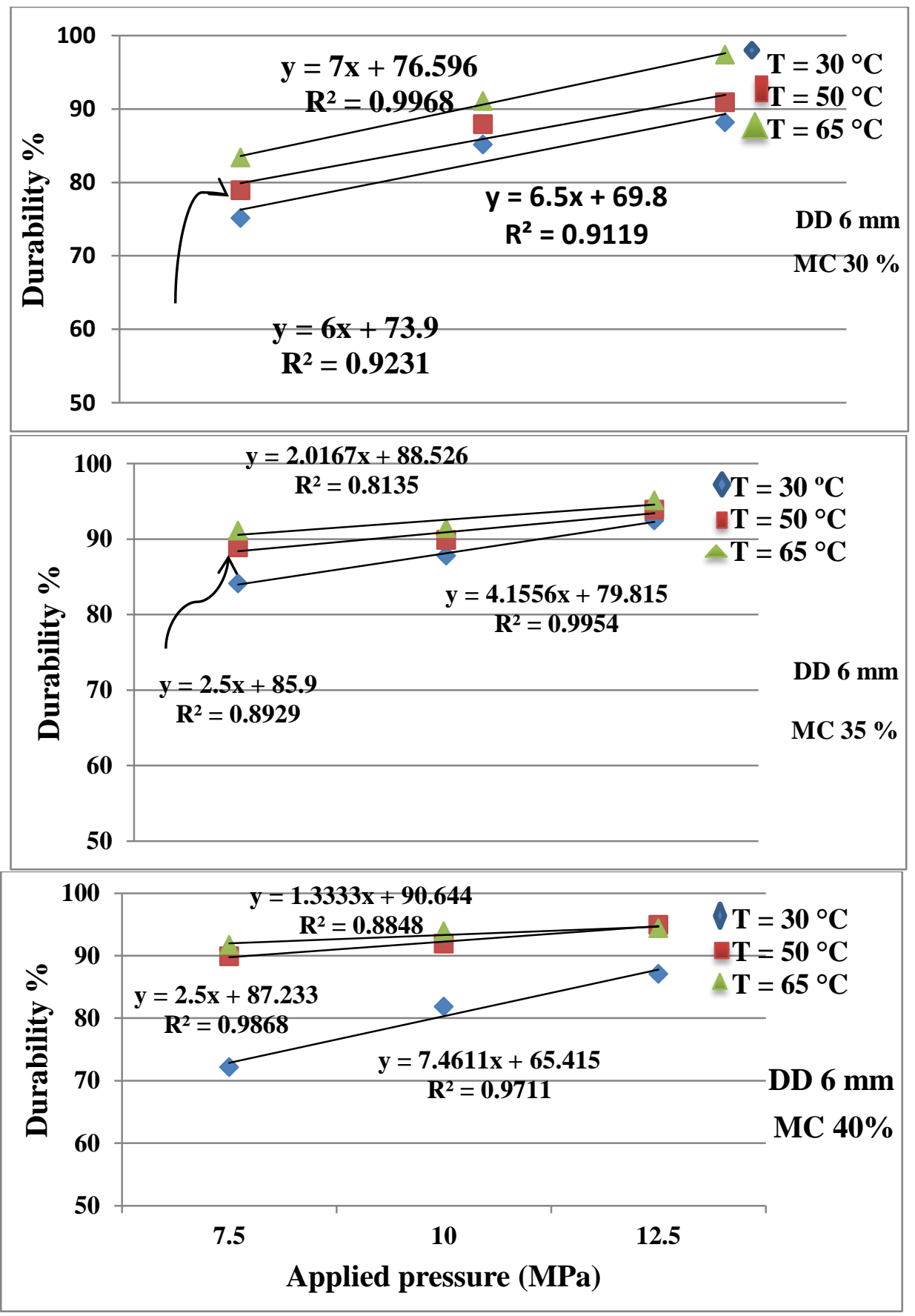

Fig.(4.1): Values of durability as affected by applied pressure and different mixing temperatures at constant moisture content w.b for die diameter $6 \mathrm{~mm}$ 


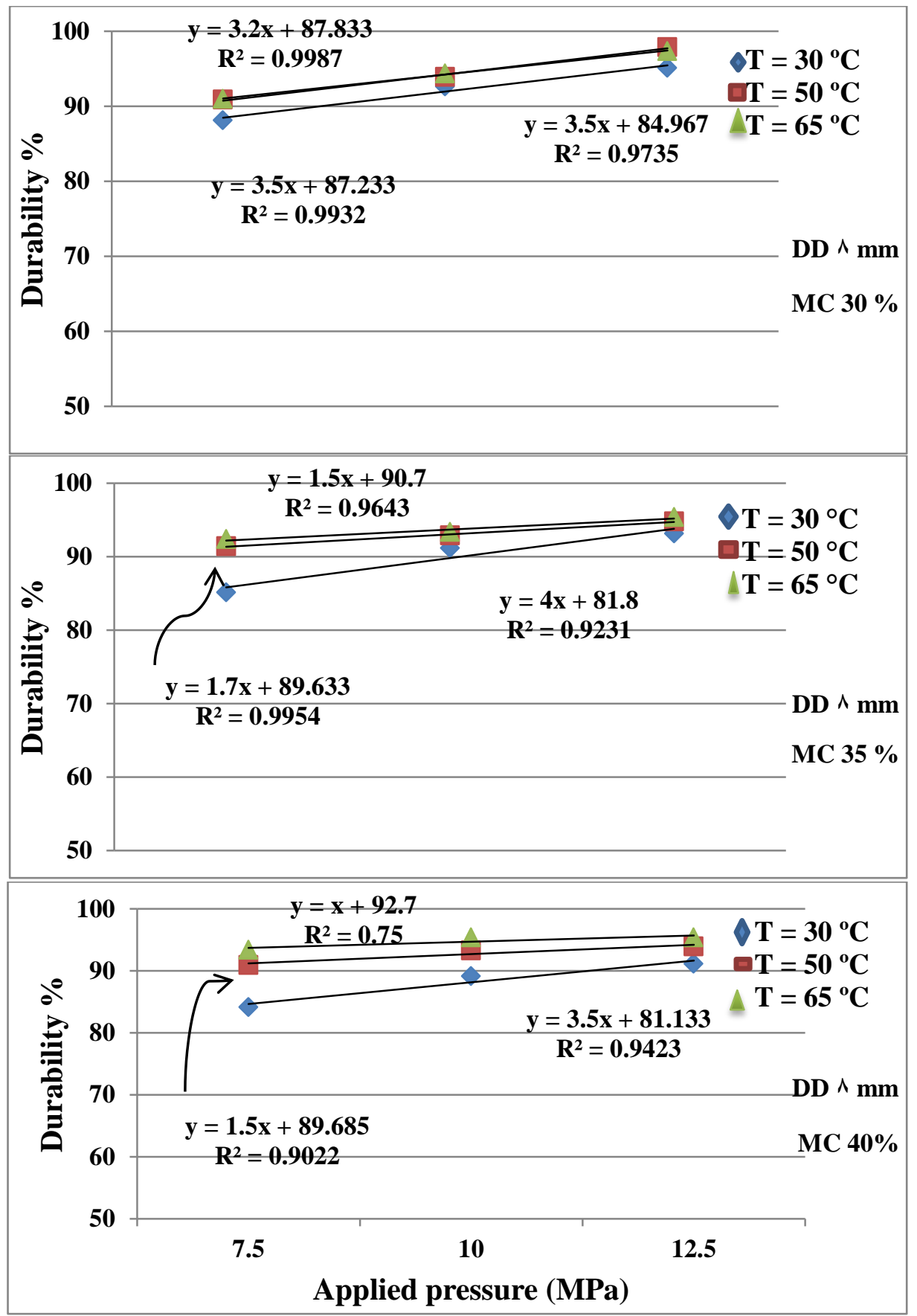

Fig.(4.2): Values of durability as affected by applied pressure and different mixing temperatures at constant moisture content w.b for die diameter $8 \mathrm{~mm}$ 


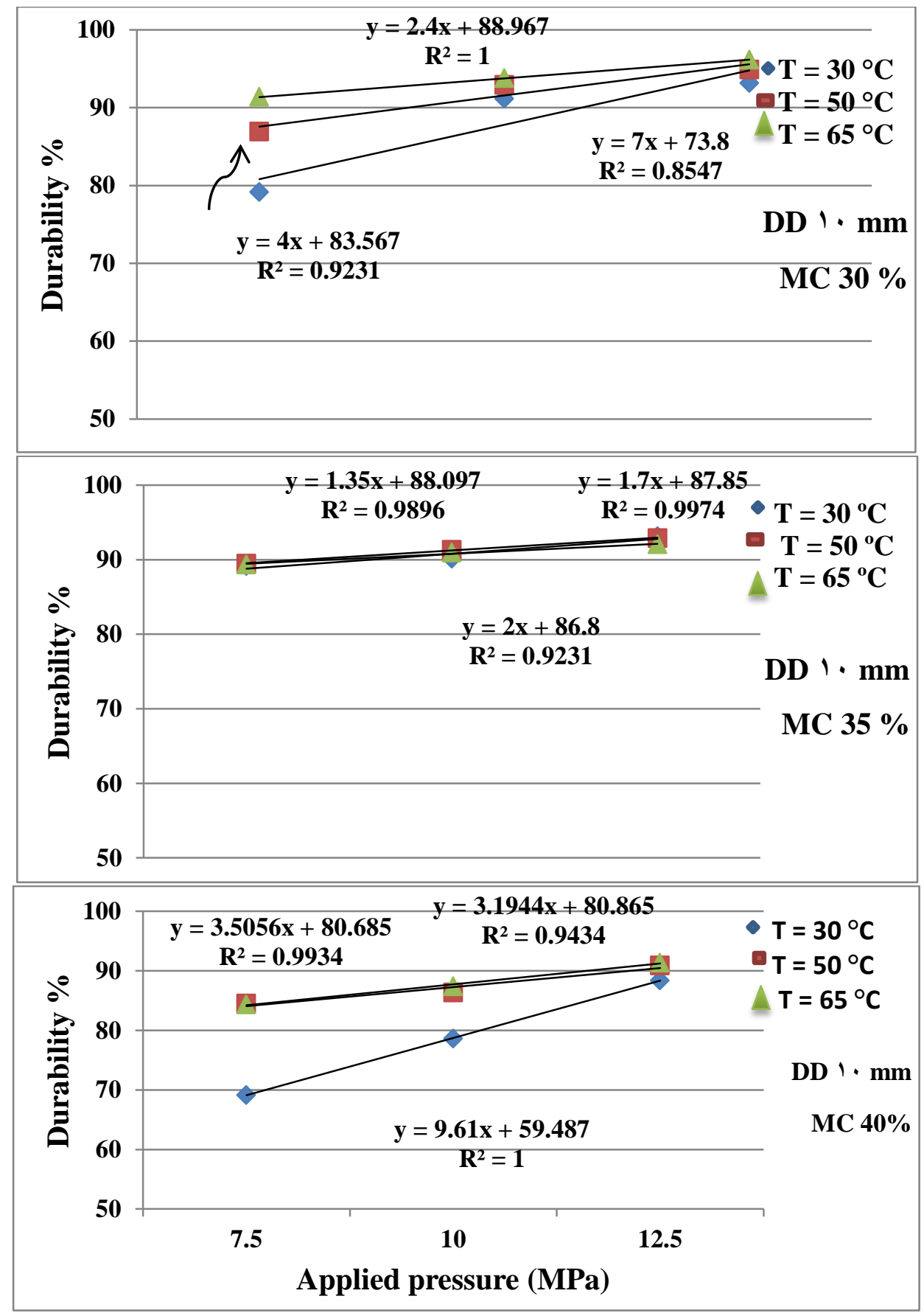

Fig.(4.3): Values of durability as affected by applied pressure and different mixing temperatures at constant moisture content w.b for die diameter $10 \mathrm{~mm}$ 


\subsubsection{Bulk and true densities of the optimal pellets construction}

Bulk and true densities of the optimal pellets were evaluated as reported in methods, Table (4.3) showed minimum and maximum values of durability and both bulk and true density evaluated and their boundary and process condition.

It is clear that bulk and true density of optimal durability $97.9 \%$ are 770.4 and $895.3 \mathrm{~kg} / \mathrm{m}^{3}$ respectively.

Comparing optimal pellets bulk and true density with that of raw sugarcane bagasse, it is clear that bulk density of pellets is 4.5 times that of raw bagasse and true density of pellets is 5.3 times bulk density of bagasse. These results showed to what extent densification process helps in transportation, storage and handling processes, moisture content $10 \%$ \pm 1 w.b of pellets is reflected to extending shelf life of these faster decomposable resides.

Table (4.3): Maximum and minimum values of pellet durability $\%$ and their true and bulk densities $\mathrm{kg} / \mathrm{m}^{3}$

\begin{tabular}{|c|c|c|c|c|c|c|c|c|}
\hline \multirow{2}{*}{ Item } & \multirow{2}{*}{$\begin{array}{c}\text { Durability } \\
\%\end{array}$} & \multirow{2}{*}{$\begin{array}{c}\text { True } \\
\text { density } \\
\text { kg/m³ }\end{array}$} & \multirow{2}{*}{$\begin{array}{c}\text { Bulk } \\
\text { density } \\
\mathrm{kg} / \mathrm{m}^{3}\end{array}$} & \multicolumn{4}{|c|}{ Process condition } & \multirow{2}{*}{ Remarlees } \\
\hline & & & & $\begin{array}{l}\text { D.D } \\
\text { mm }\end{array}$ & $\begin{array}{c}\text { M.C } \\
\%\end{array}$ & $\begin{array}{c}\mathbf{P} . \\
\mathbf{M P a}\end{array}$ & $\begin{array}{l}\text { T. } \\
{ }^{\circ} \mathbf{C}\end{array}$ & \\
\hline Max. & 97.9 & 895.3 & 770.4 & 8 & 30 & 12.5 & 50 & Optimal \\
\hline Min. & 69.1 & 724.9 & 530.9 & 10 & 40 & 7.5 & 35 & \\
\hline
\end{tabular}

\subsection{Cost analysis}

Table (4.4) and Figs. (4.4), (4.5) showed that hourly costs of pelleting machine were $16.25 \mathrm{LE} / \mathrm{hr}$.

Figs. (4.4), (4.5) depicted that the cost of producing one ton of the alternative feed produced for large animals for $8 \mathrm{~mm}$ die at $12.5 \mathrm{MPa}$ and $30 \%$ moisture content treatment recommended as an optimal pellet produced using linear programing was 2216.81 L.E./ton as compared to 3000 L.E./ton of traditional marketed feed for large animals with same nutritional value i.e. protein content and other feed components.

These results cleared that one ton of produced alternative feed in the present work cost $74 \%$ of common traditional marketing feeds, and decreasing the costs of one ton cost by $26 \%$ or 780 L.E per one ton Fig.(4.5). On the other hand, decreasing pollution caused by residues 
incineration through open burning areas, and directly affects the environment due to reducing the emittance of the greenhouse gases and decreasing also atmospheric and ground temperatures, protecting human beings from a fatal effect.

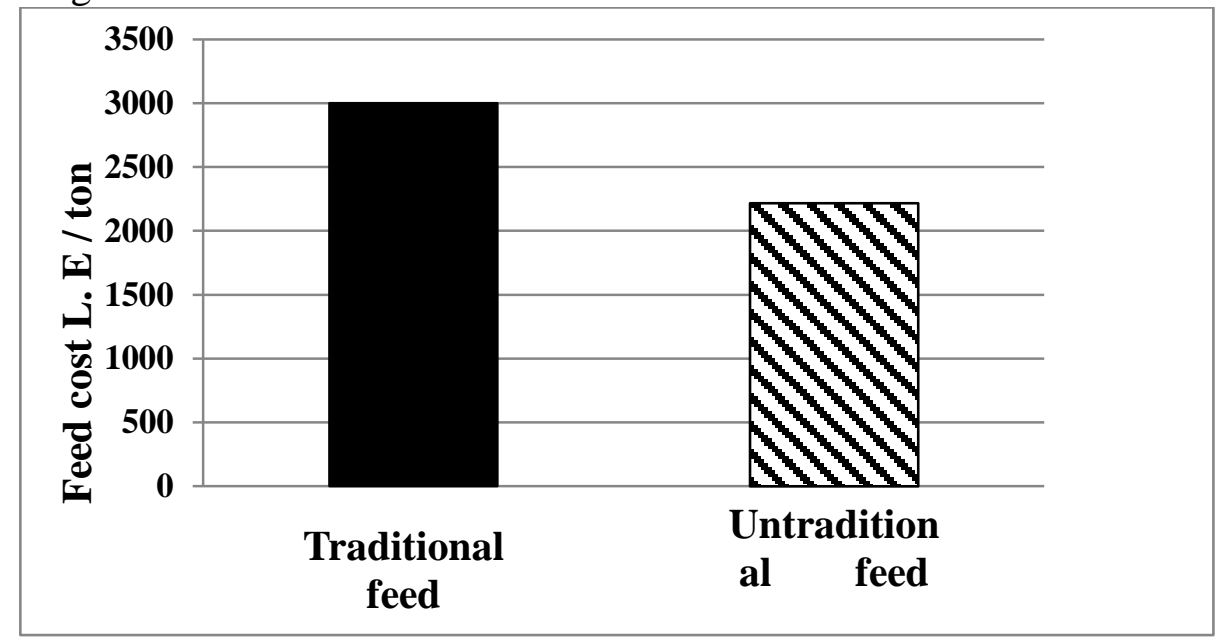

Fig. (4.4): Cost analysis of untraditional large animals feed L.E/ton

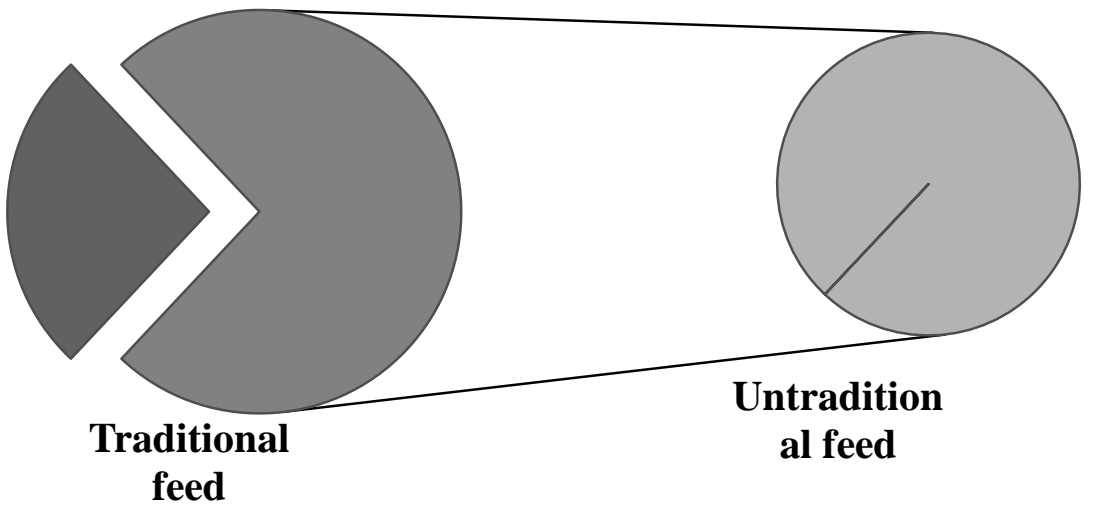

Fig.(4.5): Comparison between traditional and untraditional large animals feed

\section{SUMMARY AND CONCLUSION}

This research was carried out for maximizing the utilization of sugarcane juicing residues with the aid of densification process, and converting it to be feed ingredient for large animals of pelletized form which play an 
important role in preventing environment of fatal effect caused by direct incineration of these residues through open burning areas. So this research was extended to include five essential points:

1- $\quad$ Linear programing using Microsoft Excel 2010 which is supported with defined molasses ratio $15 \%, 10 \%$ salt, vitamins, minerals and the following other undefined quantities of soya ,corn, bagasse, bran. Proximate analysis of these undefined quantities based on NRC 1994 are used. The output of the program were

- $\quad$ For molasses ratio of $\mathbf{1 5} \%$ the output of the model was: Soya $=21 \%$, corn $=0$, bagasse $=25 \%$, bran $=29 \%$, salt, vitamins, and minerals $=10 \%$.

Results concluded that:

- There is direct proportion between all quality items and the applied pressures and mixture temperatures.

- Linear form is satisfied for specifying relationships between quality items and the applied pressures.

- $\quad$ Optimal pellet processed is selected based on durability of $97.9 \%$. The following are boundary conditions used for these pellets processing: $8 \mathrm{~mm}$ die diameter, $12.5 \mathrm{MPa}$ applied pressure, $30 \%$ moisture contents wet basis and processing temperature of $50{ }^{\circ} \mathrm{C}$.

- $\quad$ Physical and mechanical characteristics of the optimal selected pellets i.e. true, bulk densities and durability were $895.3,770.4 \mathrm{~kg} / \mathrm{m}^{3}$ and $97.9 \%$ respectively.

2- $\quad$ Cost analysis of the selected optimal alternative large animal feed of the same nutrient components showed that one ton of the alternative feed costs 2216.81 L.E. compared to 3000 L.E. of the marketed traditional one i.e. it is cheaper by $26 \%$ than that of the marketed traditional one. On the other hand using 400000 ton of bagasse in animal feeding serves in preventing environment of fatal effects of direct incineration of these residues in open areas.

\section{RCOMMENDATIONS}

1- Optimal operating conditions to produce the pelletized alternative large animal feed ration formulation are: die diameter of $8 \mathrm{~mm}$, applied pressure of $12.5 \mathrm{MPa}$, mixture temperature and moisture content wet basis $50{ }^{\circ} \mathrm{C}$ and $30 \%$ respectively. 
2- $\quad$ Using the huge amount of the bagasse residues in producing this recommended animal feed, serves in preventing environment of fatal effects of direct incineration of these residues in open areas.

3- $\quad$ Using the huge amount of the bagasse residues in producing this recommended animal feed, helps increases meat production and may be considered to be a solution of animal feeds and meat crises.

4- $\quad$ Using the huge amount of the bagasse residues in producing this recommended animal feed may change the position of Egypt from animal feeds and meat importing country to be satisfied or exporting county which can be reflected on the foreign currency reserve.

\section{REFERANCES}

Abedin, Z; and H. K. Mohammad, (2012). Livestock manure management and pelleting. Agric Eng Int: CIGR Journal, 14(3): 7884.

Adapa, P.K., Schoenau, G.J., Tabil, L.G., Arinze, E.A., Singh, A., and Dalai, A.K. (2007). Customized and value-added high quality alfalfa products - a new concept. Agricultural Engineering International: the CIGR Ejournal, Manuscript FP 07 003, IX(June), pp. $1-28$

Adapa, P.K., Tabil, L.G., and Schoenau, G.J. (2010). Compression Characteristics of Non- Treated and Steam Exploded Barley, Canola, Oat and Wheat Straw Grinds. ASABE Journal of Applied Engineering in Agriculture, 26(4), pp. 617-632

Al-Widyan, M. I., and Al-Jalil H.F. (2001). Stress-density relationship and energy requirement of compressed olive cake. Applied Eng. In Agric. 17(6): 749-753.

ASABE, (2002). Cubes, pellets, and crumbles--definitions and methods for determining density, durability, ASABE Standard, S269.4, St. Joseph, MI.

ASAE, (2003). ASAE S358.2: Moisture measurement - Forages (50th ed.). St. Joseph, MI: American Society of Agricultural Engineers p. 517-527.

Awady, M. N., (1978). Engineering of tractors and agricultural machinery, Text Bk.,col. Ag., Ain-shams U., 5 th. Ed.:164-167. (In Arabic.) (Updating 1998). 
Kaliyan, N. and Morey, R.V. (2009). Densification Characteristics of Corn Stover and Switchgrass. Transactions of the ASABE, 52(3), pp. 907-920.

Mani, S., Tabil, L.G. and Sokhansanj, S. (2004). Evaluation of compaction equations applied to four biomass species. Canadian Biosystems Engineering, 46(3), pp. 3.55-3.61.

Ministry of Agriculture, (2014). Agriculture economics. Bull. Centeral dept. of Agric., Mini. Eco. Cairo. Egypt. Part 1 publ. By Agric. Res. Senter.

Narendra, R. and Yang, Y. (2005). Biofibers from agricultural byproducts for industrial applications. Trends in Biotechnology, Volume 23, Issue 1, January, pp.22-27

NRC, (1994). Nutrient Requirements of ruminants. Washington, D.C: National Academy Press.

Peter, I. H., (2014). Processing and refinement of biogenous residues processes from agricultural, industrial and biotechnological processes. University of Technology Cottbus- Senftenberg, Germany Pp. 70-72

Samson, R; and P. Duxbury, (2000). Assessment of Pelletized Biofuels, Resource efficient agricultural production - Canada: April 2000

Shankar, T.J., K. Xingya, S. Sokhansanj, C.J. Lim, X. Bi and S. Melin. (2007). Studies on off- gassing during storage of wood pellets. ASABE Paper No. 071022. Minneapolis, MN: American Society of Agricultural and Biological Engineers.

Serrano, C., Monedero, E., Laupuerta, M., and Portero, H. (2011). Effect of Moisture Content, Particle Size and Pine Addition on Quality Parameters of Barley Straw Pellets. Fuel Processing Technology, 92(2011), pp. 699-706.

Sokhansanj, S., Mani, S., Bi, X., Zaini, P., and Tabil, L.G. (2005). Binderless pelletization of biomass. ASAE Annual International Meeting, Tampa Convention Centre, Tampa, Florida July 17-20, Paper Number 056061, 2950 Niles Road, St. Joseph, MI 490859659 USA. 


\section{الملخص العربحى

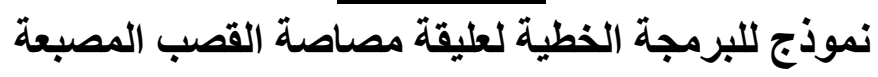

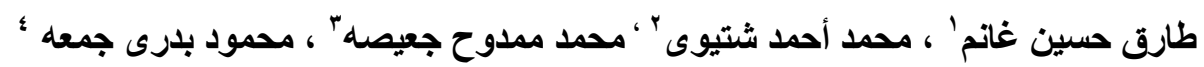

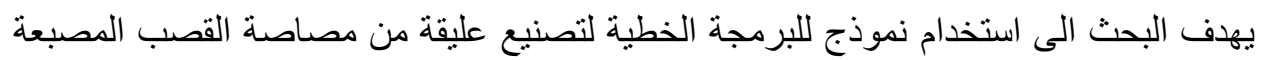

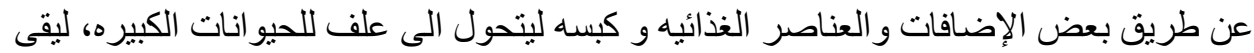

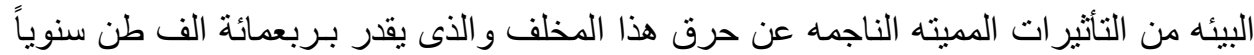

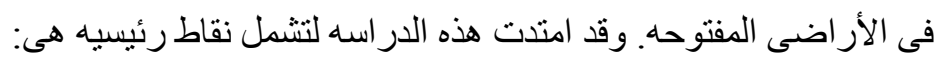

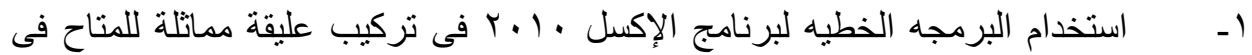

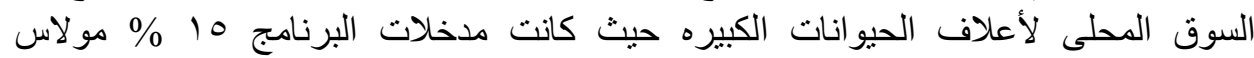

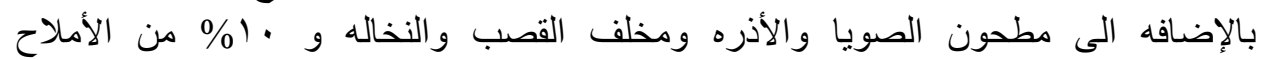

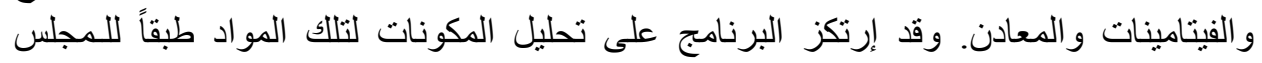

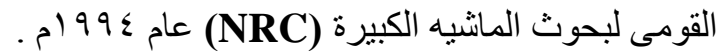

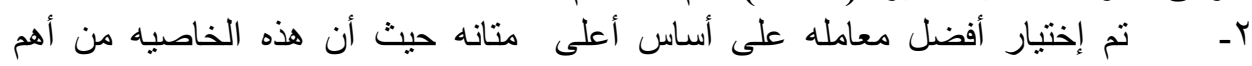

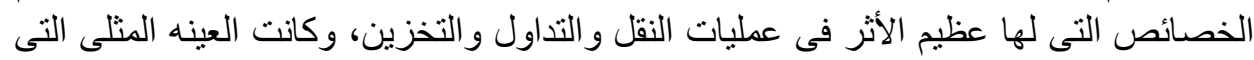

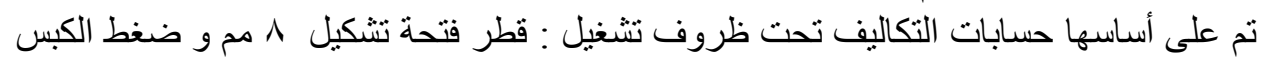

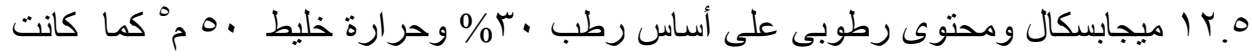

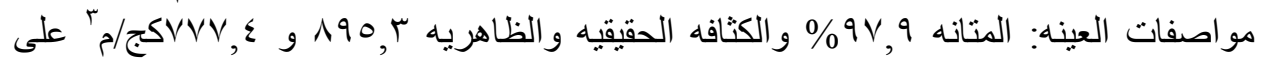

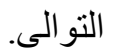

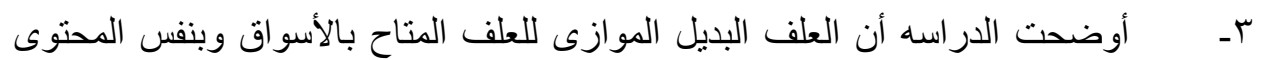

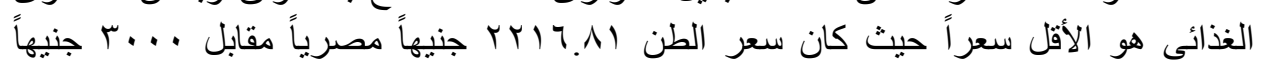

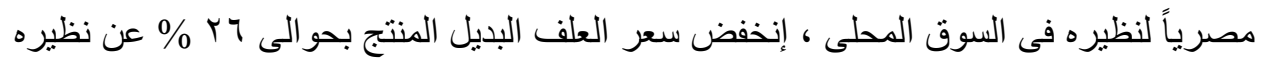

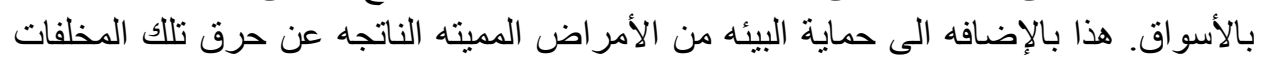

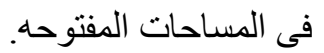
التوصيات

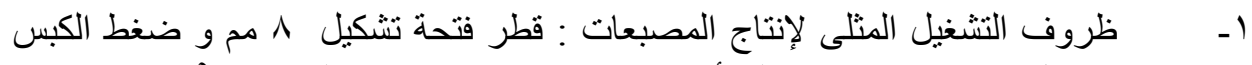

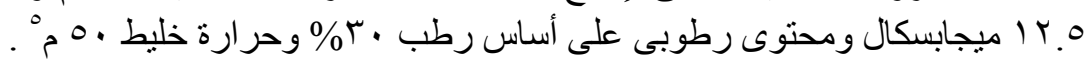

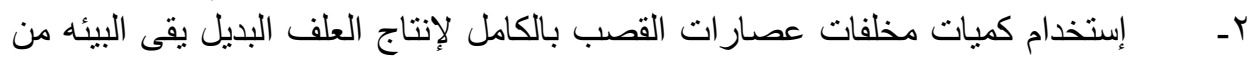

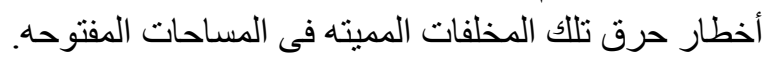

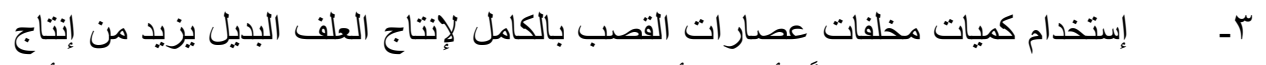

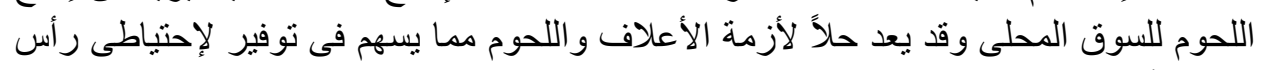

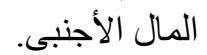
ع - توفير وفتح مجالات جديده لتنغيل الثباب و العماله.

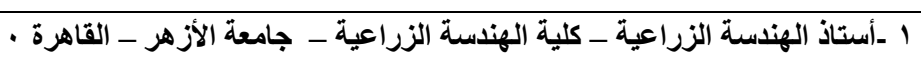

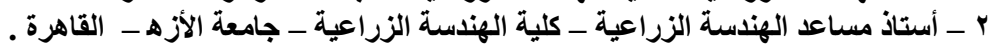

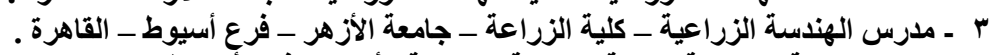

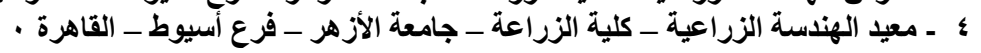

